OPEN ACCESS

Edited by:

Christoph Aebi,

University Children's Hospital

Bern, Switzerland

Reviewed by:

Genevieve McKew,

New South Wales Health

Pathology, Australia

Jesús Saavedra-Lozano,

Gregorio Marañón Hospital, Spain

${ }^{*}$ Correspondence:

Pierre R. Smeesters

psmeeste@ulb.ac.be

Specialty section:

This article was submitted to Pediatric Infectious Diseases,

a section of the journal

Frontiers in Pediatrics

Received: 20 April 2021

Accepted: 19 July 2021

Published: 20 August 2021

Citation:

Laho D, Blumental S, Botteaux A and Smeesters PR (2021) Invasive Group A Streptococcal Infections: Benefit of

Clindamycin, Intravenous Immunoglobulins and Secondary Prophylaxis. Front. Pediatr. 9:697938.

doi: $10.3389 /$ fped.2021.697938

\section{Invasive Group A Streptococcal} Infections: Benefit of Clindamycin, Intravenous Immunoglobulins and Secondary Prophylaxis

\author{
Delphine Laho ${ }^{1,2}$, Sophie Blumental ${ }^{1}$, Anne Botteaux ${ }^{2}$ and Pierre R. Smeesters $1,2,3,4 *$ \\ 1 Paediatric Department, Academic Children Hospital Queen Fabiola, Université Libre de Bruxelles, Brussels, Belgium, \\ ${ }^{2}$ Molecular Bacteriology Laboratory, Université Libre de Bruxelles, Brussels, Belgium, ${ }^{3}$ Tropical Diseases Research Group, \\ Murdoch Children's Research Institute, Melbourne, VIC, Australia, ${ }^{4}$ Department of Paediatrics, University of Melbourne, \\ Melbourne, VIC, Australia
}

Introduction: Mortality associated with invasive group A streptococcal infections (iGAS) remains high among adults, with lower mortality in children. The added value of both clindamycin and immunoglobulins in such treatment is still controversial, as is the need for antibiotic secondary prophylaxis. It is unlikely that conclusive randomized clinical studies will ever definitively end these controversies.

Materials and Methods: A clinical and experimental literature review was conducted in Pubmed, Cochrane, and lay literature to determine the benefit of adding clindamycin and immunoglobulins to $\beta$-lactams in the management of iGAS, as well as the need for secondary prophylaxis measures in close contacts.

Results: This review includes two meta-analyses, two randomized controlled trials, four prospective studies, five retrospective studies, and microbiological studies. To reduce mortality and morbidity, it appears useful to add clindamycin to $\beta$-lactams in severe clinical presentations, including necrotizing fasciitis or streptococcal toxic shock syndrome, and immunoglobulins for the latter two presentations. The high risk of secondary infection in household contacts justifies the need of taking preventive measures.

Conclusions: Both clinical studies and available experimental evidence suggest that adding clindamycin and immunoglobulins as adjunctive therapies in the management of invasive group A streptococcal infections may reduce mortality. Household contacts should be warned about the increased risk of secondary infection, and chemoprophylaxis may be considered in certain situations.

Keywords: invasive group A streptococcal infections, clindamycin, immunoglobulins, secondary prophylaxis, chemoprophylaxis

\section{INTRODUCTION}

Group A Streptococcus (GAS) causes a wide spectrum of clinical syndromes ranging from asymptomatic carriage to life-threatening infections. Invasive Group A Streptococcal infections (iGAS) are defined by the isolation of GAS from a normally sterile site (e.g., blood, pleural, or cerebrospinal fluid) with or without clinical evidence of invasive diseases or a deep-seated infection 
[necrotising fasciitis (NF), pneumonia, osteomyelitis] (1). IGAS affect 663,000 people each year globally and cause 163,000 deaths (2). Although GAS is always sensitive to penicillin [even if some mutations in penicillin-binding protein genes conferring reduced susceptibility to $\beta$-lactam antibiotics have been reported (3)], the mortality from these infections remains high, especially among adults which can reach up to $24 \%$ for NF and $36 \%$ for streptococcal toxic shock syndrome (STSS) (4), with lower mortality in children in high-resource settings. Numerous virulence factors have been shown to contribute to GAS virulence. Exotoxins that act as superantigens and activate the immune system were associated with several clinical syndrome including STSS $(1,5)$. The M protein promotes GAS infection by various means including the inhibition of phagocytosis (6). GAS also produces enzymes that prevent GAS from being killed like SpeB, a protease degrading host and bacterial components (7), Sda1, a DNAse destroying neutrophils extracellular traps (8), and toxins like Streptolysin O (SLO) cytotoxic for macrophages and neutrophils (6). Appropriate diagnostic and rapid treatment based on $\beta$-lactam antibiotics and supportive care are the most important factors in reducing mortality (9). However, variety of treatment protocols exists particularly in the potential use of adjuvant therapies such as clindamycin and intravenous immunoglobulins (IVIG) (Table 1). Although their use is overall supported by both biological and microbiological experimental data, as well as by observational studies, conclusive clinical data supporting their efficacy in reducing iGAS mortality remain limited. In addition, an increased risk of secondary iGAS infections in close contacts from the index case has been described $(10,19)$. Whether antibiotic secondary prophylaxis allows for a reduction in secondary cases remains uncertain. We aimed to summarize the available experimental and clinical evidence about the efficacy of adding clindamycin and IVIG to $\beta$ lactams in the management of iGAS. We also aimed to assess the benefits and optimal regimen of antibiotic prophylaxis in close contacts of patients.

\section{MATERIALS AND METHODS}

A clinical and experimental literature review was conducted in Pubmed, Cochrane, and lay literature (governmental websites, pharmacology website, and books) using the following keywords: « (group A streptococcus OR Streptococcus pyogenes) AND (invasive infections OR toxic shock syndrome OR necrotizing fasciitis) AND (treatment OR immunoglobulin OR clindamycin OR secondary OR prophylaxis OR prophylactic OR contact OR family OR household). $\gg$ The articles were selected regarding their language (English and French) without any time limit. The initial search resulted in 1,438 articles; among which, 1,293 were excluded based on their title and abstract (irrelevant articles about other treatments than clindamycin and IVIG, other pathogens than GAS, non-invasive streptococcal diseases, and low-quality studies). We also checked the references of the selected articles for relevant articles. In total, 149 articles were read entirely and 59 articles were included in this review.

\section{Benefit of Intravenous Immunoglobulins in iGAS Management}

The rationale for adding intravenous immunoglobulins (IVIG) to iGAS treatment is based on the major inflammatory response leading to systemic toxicity and multiple organ failure. The trigger for this excessive reaction relies on both host factors (genetic influence, absence of prior immunity against GAS) and the characteristics of the pathogen [expression of certain M proteins, DNases (20), and superantigens]. IVIG consist of a mixture of human IgG antibodies collected from thousands of donors. In adjuvant therapy, IVIG could act by promoting opsonization and phagocytosis of bacteria, neutralizing toxins, and exerting an immunomodulatory effect (21).

In addition, the actions of IVIG have been demonstrated in vitro and in mice experimental models, including neutralization of circulating superantigens and reduction of the systemic inflammatory response $(22,23)$. A recent study analyzed the effects of IVIG on virulence factor activity in three different ways: in vitro, in vivo in a murine infection model, and ex vivo in patients (24). In vitro, SLO and Sda1 activities were reduced. In the murine infection model, mice treated with IVIG had smaller skin lesions and a lower SLO activity. Moreover, serum from patients with iGAS had a reduced SLO and Sda activity after IVIG was administrated compared with before such treatment (24). In addition, plasma of STSS-patients treated with IVIG was able to neutralize streptococcal superantigens and completely inhibit cytokine production (25), suggesting a clinical interest of such adjunctive therapy for these patients. A recent study demonstrated that one 25-g IVIG dose was sufficient to achieve plasma neutralization of GAS superantigenic activity. The study showed a negative correlation between IVIG dose and toxintriggered T-cell proliferation $(r=-0.67, p<0.0001)$ (26). It also demonstrated a strain-dependant variation in the IVIG effect (26).

As shown in Table 2, several studies have been conducted to evaluate the benefit of IVIG in iGAS management. Two prospective studies of 53 Canadian and 67 Swedish STSS patients reported that IVIG use was associated with a lower mortality [respectively, survival OR: 8.1 (95\% IC, 1.6-45; $p=0.009$ ) (27) and OR survival: 5.6; IC 95\%: 1.2-2.9, $p=0.03$ (21)]. In addition, a multicenter, randomized, placebo-controlled trial in 17 hospitals on 21 patients with STSS, with or without necrotizing fasciitis, evaluating the efficacity of adding IVIG to the bitherapy penicillin-clindamycin demonstrated a higher mortality in the group who did not receive IVIG (Death rate: 3.6 times higher in the placebo group, $p=0.3$ ) (28). This finding was statistically non-significant, probably because of the small number of patients included. Initially, the study was designed to include 120 patients but the slow patient recruitment interrupted the trial prematurely (28). A retrospective study on 322 patients with NF failed to show any benefit of IVIG regarding mortality or hospital length of stay (29). Nevertheless, the patients who received IVIG were much more ill, which could have underestimated a positive effect of IVIG (29). Recently, a blinded, randomized, placebocontrolled clinical trial assessing the effect of IVIG vs. placebo in 100 adult patients with necrotizing soft tissue infections did 
TABLE 1 | Guideline.

\begin{tabular}{|c|c|c|c|}
\hline $\begin{array}{l}\text { Countries/ } \\
\text { Recommendations }\end{array}$ & IVIG & Clindamycin & Secondary prophylaxis \\
\hline $\begin{array}{l}\text { Common } \\
\text { recommendations }\end{array}$ & None & None & $\begin{array}{l}\text { - For all: inform close contacts } \\
\text { - Seek medical attention promptly if symptoms occur } \\
\text { - Antibiotics to close contacts if they present any symptoms of a localized infection with } \\
\text { GAS (angina, fever, skin infection, etc.) }(1,10-13)\end{array}$ \\
\hline USA & $\begin{array}{l}\text { Infection refractory } \\
\text { to aggressive } \\
\text { treatment or a } \\
\text { non-drainable focus } \\
\text { or an oliguria } \\
\text { persistence with } \\
\text { pulmonary oedema } \\
(14)\end{array}$ & $\begin{array}{l}\text { Severe GAS } \\
\text { infection }^{\circ}(14)\end{array}$ & $\begin{array}{l}\text { - Chemoprophylaxis to household contacts who have a high risk of iGAS (age } \geq 65 \text { years, } \\
\text { HIV infection, diabetes, cancer, heart disease, addiction, corticosteroids, Native American } \\
\text { origin), or death }(10,14) \\
\text { - Penicillin + rifampicin } \\
\text { - Clindamycin } \\
\text { - Azithromycin }(10,14)\end{array}$ \\
\hline Canada & $\begin{array}{l}\text { Severe GAS } \\
\text { infection or } \\
\text { infection refractory } \\
\text { to aggressive } \\
\text { treatment (15) }\end{array}$ & $\begin{array}{l}\text { Severe GAS } \\
\text { infection }^{\circ}(15)\end{array}$ & $\begin{array}{l}\text { - Chemoprophylaxis to close contacts of a patient with a severe iGAS } \\
\text { - Chemoprophylaxis to close contacts if two or more cases occur in a community within } \\
1 \text { month } \\
\text { - chemoprophylaxis to close contacts if a case in a child care center occurs at the same } \\
\text { time as a chickenpox outbreak } \\
\text { - } 1 \text { st choice: } 1 \text { st generation cephalosporins } \\
\text { - If beta-lactams allergy: clindamycin or macrolides (15) }\end{array}$ \\
\hline United Kingdom & No consensus & No consensus & $\begin{array}{l}\text { - Chemoprophylaxis to a mother or her child if either has an iGAS during the neonatal } \\
\text { period (the first } 28 \text { days of life) } \\
\text { - Chemoprophylaxis to close contacts if two or more cases occur in a community within } \\
1 \text { month } \\
\text { - 1st choice: oral penicillin } \\
\text { - If beta-lactams allergy: azithromycin (12) }\end{array}$ \\
\hline Ireland & $\begin{array}{l}\text { STSS or NF if } \\
\text { associated with } \\
\text { organ failure (16) }\end{array}$ & $\begin{array}{l}\text { Suspected severe } \\
\text { infection }^{\circ}(16)\end{array}$ & $\begin{array}{l}\text { - Chemoprophylaxis to a mother or her child if either has an iGAS during the neonatal } \\
\text { period (the first } 28 \text { days of life) } \\
\text { - Chemoprophylaxis to close contacts if two or more cases occur in a community within } \\
1 \text { month } \\
\text { - 1st choice: oral penicillin } \\
\text { - If beta-lactams allergy: azithromycin (16) }\end{array}$ \\
\hline France & STSS or NF & $\begin{array}{l}\text { NF, STSS, or toxin } \\
\text { signs (rash, digestive } \\
\text { or hemodynamic } \\
\text { disorders) (17) }\end{array}$ & $\begin{array}{l}\text { - Chemoprophylaxis to close contacts at risk of iGAS or complications (age } \geq 65 \text { years, } \\
\text { chickenpox, extensive skin lesions (including burns), drug addiction, progressive } \\
\text { pathology (diabetes, cancer, hematology, HIV infection, heart failure), oral corticosteroid } \\
\text { treatment (defined as doses }>5 \mathrm{mg} / \mathrm{kg} / \text { day prednisone for more than } 5 \text { days or doses } \\
\text { equivalent to or }>0.5 \mathrm{mg} / \mathrm{kg} / \text { day prednisone for } \geq 30 \text { days) } \\
\text { - 1st choice: } 2 \text { nd or } 3 \mathrm{rd} \text { generation cephalosporins } \\
\text { - If beta-lactams allergy: clindamycin or macrolides } \\
\text { - If macrolide-resistant GAS: oral penicillin + rifampin (13) }\end{array}$ \\
\hline Australia & No consensus & No consensus & $\begin{array}{l}\text { - Chemoprophylaxis to close contacts of patient with a severe iGAS } \\
\text { - Chemoprophylaxis to a mother or her child if either develops an iGAS in the neonatal } \\
\text { period (the first } 28 \text { days of life) } \\
\text { - Chemoprophylaxis to close contacts if two or more cases occur in a community within } \\
3 \text { months } \\
\text { - 1st choice: benzathine penicillin (intramuscular) } \\
\text { - 2nd choice if oral therapy preferred: cephalexin } \\
\text { - If beta-lactams allergy: macrolides } \\
\text { - If macrolide-resistant GAS or pregnant women: clindamycin (11) }\end{array}$ \\
\hline Belgium (Flanders) & No consensus & No consensus & $\begin{array}{l}\text { - Chemoprophylaxis to all household contacts of the index case } \\
\text { - 1st choice: azithromycin } \\
\text { - If macrolide-resistant GAS or pregnant women: clindamycin (18) }\end{array}$ \\
\hline Our recommendations & $\begin{array}{l}\text { All hemodynamically } \\
\text { unstable patients } \\
\text { and/or admitted to } \\
\text { intensive care unit } \\
\text { and/or having STSS } \\
\text { or NF }\end{array}$ & $\begin{array}{l}\text { For all hospitalized } \\
\text { iGAS infections }\end{array}$ & $\begin{array}{l}\text { - Chemoprophylaxis to all household members of the patient } \\
\text { - Chemoprophylaxis to people at high risk of complications or deaths related to iGAS } \\
\text { - 1st choice: first-generation cephalosporins } \\
\text { - If beta-lactams allergy: macrolides } \\
\text { - If macrolide-resistant GAS or pregnant women: clindamycin }\end{array}$ \\
\hline
\end{tabular}

- Severe iGAS refers to iGAS such as pneumonia, meningitis, NF, STSS, or any manifestation requiring admission to intensive care or leading to death. 
not demonstrate any effect on self-reported physical functioning at 6 months nor in mortality or organ failure [Risk Ratio (RR) mortality: 0.80 ; IC $95 \% 0.40-1.59 ; p=0.65$ ] (30). However, the potential effect of IVIG could have been hidden by the single dose of IVIG received by nearly half of the patients in the placebo group before the randomization (30). A single dose of 25-g IVIG indeed has an effect on GAS superantigenic activity (26).

Focusing on a pediatric setting, only a few studies were published in children with iGAS. Children with STSS had a lower mortality rate than adults making demonstration of a benefit in clinical studies even more complicated (4). An American retrospective study on 192 children with STSS did not show any difference in mortality whether IVIG was used or not (4.5\% in both groups, $p=1$ ) (31). However, the low mortality rate observed in both groups interrogates about the STSS case definition and severity of included patients. In a multicenter, retrospective 2014 study on 49 children, IVIG was not given to children who died and no death happened in the IVIG-group (32). However, as this study was based on a questionnaire sent to institutions that first agreed to participate and not all reported back, there may have been a higher risk of methodological bias (32). An Australian prospective study on children and adults found a decrease in mortality when IVIG were added to penicillin and clindamycin (19). A Cochrane review published in 2013 on adults and children, including 17 randomized controlled trials, showed the use of IVIG decreases the mortality in cases of sepsis in adults (RR 0.77; 95\% CI 0.68-0.87), irrespective of the pathogen responsible which limits the impact on GAS specific sepsis (33). A subanalysis including only studies considered to have a lower risk of bias did not retrieve the same conclusion in adults and neonates (RR 0.97; 95\% CI $0.81-1.15 ; n=945$ ) (33). A meta-analysis conducted by Parks et al., including studies on adults and children, showed that the IVIG on clindamycintreated patients significantly reduced STSS related-mortality from 33.7 to $15.7 \%$ (RR: 0.46 ; IC 95\%: $0.26-0.83 ; p=0.01$ ) (34). Nevertheless, some biases are possible due to non-RCT studies included in this meta-analysis (34).

Current recommendations regarding IVIG treatment in iGAS vary (Table 1). The American Academy of Pediatrics recommend the use of IVIG in case of infection refractory to aggressive treatment or a non-drainable focus or an oliguria persistence with pulmonary edema (14), whereas the French Society of Pediatrics advises the use of IVIG in case of STSS or NF (17). In Ireland, IVIG are considered for STSS or NF if associated with organ failure (16). The dosages used are $1 \mathrm{~g} / \mathrm{kg}$ on the first day then $0.5 \mathrm{~g} / \mathrm{kg}$ for the following 2 days. However, no study has been performed to define the optimal dosage or schedule of administration (14). Side effects are rare, with anaphylactic reaction being the most serious (38). Moreover, IVIG cost is not negligible (45 euros per gram) (38). However, regarding their efficacy and the low risk of side effects, we recommend the administration of IVIG in all hemodynamically unstable patients and/or admitted to intensive care unit and/or having STSS or NF. Hemodynamic status has to be evaluated before IVIG administration as it can be compromised in critically ill patients who may not tolerate large amount of liquids.

\section{Benefit of Clindamycin in iGAS Management}

The adjunction of a second antibiotic, clindamycin, to the conventional beta-lactam therapy is widely used and has been evaluated by several in vitro and in vivo studies (35). Clindamycin has an excellent tissue penetration in vitro and a long effect after administration. Moreover, it remains active regardless of the size of the bacterial inoculum or growth stage (3). This contrasts with $\beta$-lactams antibiotics which are known to be less efficient when the bacterial inoculum increases so much that most of them are in stationary replication phase (Eagle effect) (39). Clindamycin therefore acts synergistically with $\beta$-lactams to reduce the bacterial load in iGAS (40).

Clindamycin inhibits protein synthesis by binding to the $50 \mathrm{~S}$ subunit of the bacterial ribosome. Clindamycin therefore blocks the transcription and production of many virulence factors involved in systemic toxicity and tissue destruction such as the $M$ proteins, superantigens, streptolysins, and DNases (41). In mice experiments comparing clindamycin vs. placebo, clindamycin has been shown to decrease the expression of DNase (Sda1) and SLO that was associated with a reduction of the cutaneous lesions size (42). In another recent experimental paper using an iGAS mice model, clindamycin improved the survival rate of infected mice and the frequency of immune cells involved in host infection defense (7).

Furthermore, some clinical studies evaluated the impact of adding clindamycin in the management of iGAS in humans (Table 2). Two studies, one including 195 adult patients with NF and another 62 adult patients with a STT, found a significant decrease in mortality in clindamycin-treated patients [respectively, odds ratio (OR) mortality: $0.11 ; 95 \%$ IC: $0.01-0.89$ (36); OR survival: 8.6; 95\% IC: $1.8-40.4 p=0.007$ ] (21). Another recent paper about 1,956 adults showed a significantly lower mortality in patients with iGAS who received clindamycin even if they did not have a vasopressor-dependent shock, NF, or both (OR mortality: 0.44; 95\% IC: 0.23-0.81) (37).

Two studies included pediatric patients. A retrospective study of 56 children in the USA showed a statistically significant decrease in mortality when clindamycin was added to a $\beta$-lactam for GAS deep-sited infection (survival with clindamycin: 83 vs. $14 \%$ without clindamycin, $p=0.006$ ) (35). An Australian prospective study following 4.9 million people over the 2.5 -year reported 84 iGAS cases (age: 3.8-88.1 years) and suggested the effectiveness of adding clindamycin on mortality (OR mortality: 0.31; IC 95\%:0.09-1.12) (19). However, their results did not reach a statistical significance, probably because of the small number of patients included in the study (19). Despite the convincing results of these observational surveys, the lack of conclusive randomized trials led to a great variability in expert recommendations. The American Academy of Pediatrics and the Canadian Pediatric Society recommend adding clindamycin to $\beta$ lactams $(30-40 \mathrm{mg} / \mathrm{kg} /$ day in 3-4 doses intravenous, maximum $1.8-2.7 \mathrm{~g} /$ day) in case of a severe GAS infection such as pneumonia, meningitis, NF, STSS, or any manifestation requiring admission to intensive care or leading to death $(14,15)$. In Ireland, clindamycin is prescribed as soon as a severe infection is suspected (16). The French Society of Pediatrics suggests 
TABLE 2 | Studies assessing the clinical efficacy of IVIG and clindamycin in iGAS.

\begin{tabular}{|c|c|c|c|c|c|c|}
\hline References & $\begin{array}{l}\text { Design } \\
\text { study }\end{array}$ & $\begin{array}{l}\text { Number } \\
\text { of } \\
\text { patients }\end{array}$ & Type of patients & Treatments compared & Results & Conclusions \\
\hline \multicolumn{7}{|l|}{ IVIG } \\
\hline $\begin{array}{l}\text { Carapetis et al. } \\
\text { (19) }\end{array}$ & $\begin{array}{l}\text { Prospective- } \\
\text { retrospective }\end{array}$ & 84 & $\begin{array}{l}\text { Children and adults } \\
\text { (Average age of the } \\
\text { two groups } \\
\text { compared: } 56.2 \text { vs. } \\
70.4 \text { years) }\end{array}$ & $\begin{array}{l}\text { Clindamycin vs. no } \\
\text { clindamycin; analyzed } \\
\text { subgroup: clindamycin + } \\
\text { IVIG vs. clindamycin without } \\
\text { IVIG }\end{array}$ & $\begin{array}{l}\text { OR mortality: } 0.12 \text { (95\% Cl: } \\
\left.0.1-1.29^{\#}\right)\end{array}$ & $\begin{array}{l}\text { IVIG further reduces mortality } \\
\text { when added to clindamycin in } \\
\text { case of STSS or NF }\end{array}$ \\
\hline Linnér et al. (21) & Prospective & 67 & $\begin{array}{l}\text { Adults (Average age } \\
\text { of the two groups } \\
\text { compared: } 60 \text { vs. } 65 \\
\text { years) }\end{array}$ & IVIG vs. no IVIG & $\begin{array}{l}\text { OR survival: } 5.6(95 \% \mathrm{Cl} \\
\left.1.2-2.9, p=0.03^{\star}\right)\end{array}$ & IVIG decrease mortality in STSS \\
\hline Kaul et al. (27) & Prospective & 53 & $\begin{array}{l}\text { Adults (Average age } \\
\text { of the two groups } \\
\text { compared: } 52 \text { vs. } 60 \\
\text { years) }\end{array}$ & IVIG vs. no IVIG & $\begin{array}{l}\text { OR survival: } 8.1(95 \% \mathrm{Cl}: \\
\left.1.6-45, p=0.009^{\star}\right)\end{array}$ & IVIG decrease mortality in STSS \\
\hline $\begin{array}{l}\text { Darenberg et al. } \\
\text { (28) }\end{array}$ & $\begin{array}{l}\text { A multicentre, } \\
\text { randomized, } \\
\text { double-blind, } \\
\text { placebo- } \\
\text { controlled }\end{array}$ & $21^{a}$ & $\begin{array}{l}\text { Adults (Average age } \\
\text { of the two groups } \\
\text { compared: } 51.3 \text { vs. } \\
52.6 \text { years) }\end{array}$ & IVIG vs. placebo & $\begin{array}{l}\text { Death rate: } 3.6 \text { times higher } \\
\text { in the placebo group }(p= \\
\left.0.3^{\#}\right)\end{array}$ & $\begin{array}{l}\text { IVIG seem to decrease mortality } \\
\text { in STSS }\end{array}$ \\
\hline Kadri et al. (29) & Retrospective & 322 & $\begin{array}{l}\text { Adults (Average age } \\
\text { of the two groups } \\
\text { compared: } 48.8 \text { vs. } \\
54 \text { years) }\end{array}$ & IVIG vs. no IVIG & $\begin{array}{l}\text { Same mortality }\left(p=0.99^{\#}\right) \\
\text { and hospital length of stay } \\
\left(p=0.84^{\#}\right) \text { in the two } \\
\text { groups }\end{array}$ & $\begin{array}{l}\text { No difference on mortality or } \\
\text { hospital length of stay in NF }\end{array}$ \\
\hline $\begin{array}{l}\text { Madsen et al. } \\
(30)\end{array}$ & $\begin{array}{l}\text { Randomized, } \\
\text { blinded, } \\
\text { placebo- } \\
\text { controlled } \\
\text { clinical trial } \\
\text { (INSTINCT) }\end{array}$ & 100 & $\begin{array}{l}\text { Adults (Average age } \\
\text { of the two groups } \\
\text { compared: } 59 \text { vs. } 61 \\
\text { years) }\end{array}$ & IVIG vs. placebo & $\begin{array}{l}\text { No effect on self-reported } \\
\text { physical functioning at } 6 \\
\text { months }\left(p=0.81^{\#}\right) \text { Same } \\
\text { mortality in the two groups }\end{array}$ & $\begin{array}{l}\text { No difference on physical } \\
\text { functioning or mortality in NF }\end{array}$ \\
\hline (31) & Retrospective & 192 & $\begin{array}{l}\text { Children (Average } \\
\text { age: } 8.8 \text { years) }\end{array}$ & IVIG vs. no IVIG & $\begin{array}{l}\text { Same mortality in the } \\
\text { two groups }\left(p=1^{\#}\right)\end{array}$ & $\begin{array}{l}\text { No difference in mortality in } \\
\text { STSS }\end{array}$ \\
\hline Adalat et al. (32) & $\begin{array}{l}\text { Prospective } \\
\text { (survey which } \\
\text { results are } \\
\text { based on } \\
\text { participating } \\
\text { centers only) }\end{array}$ & 49 & $\begin{array}{l}\text { Children (Average } \\
\text { age: } 4.8 \text { years) }\end{array}$ & IVIG vs. no IVIG & No death in the IVIG group & IVIG decrease mortality in STSS \\
\hline $\begin{array}{l}\text { Alejandria et al. } \\
\text { (33) }\end{array}$ & Meta-analysis & 1958 & $\begin{array}{l}\text { Children and adults } \\
\text { (Average age not } \\
\text { mentioned) }\end{array}$ & $\begin{array}{l}\text { IVIG vs. placebo or no } \\
\text { intervention }\end{array}$ & $\begin{array}{l}\text { RR mortality: } 0.77 \text { (95\% Cl: } \\
\left.0.68-0.87^{\star}\right)\end{array}$ & $\begin{array}{l}\text { IVIG decrease mortality in adults } \\
\text { with septic shock, no matter the } \\
\text { bacteria involved }\end{array}$ \\
\hline Parks et al. (34) & Meta-analysis & 165 & $\begin{array}{l}\text { Children and adults } \\
\text { (Average age not } \\
\text { mentioned) }\end{array}$ & $\begin{array}{l}\text { IVIG vs. no IVIG in } \\
\text { clindamycin-treated patients } \\
\text { with STSS }\end{array}$ & $\begin{array}{l}\text { RR mortality: } 0.46(95 \% \mathrm{Cl} \text { : } \\
\left.0.26-0.83^{\star}\right)\end{array}$ & IVIG decrease mortality in STSS \\
\hline \multicolumn{7}{|l|}{ Clindamycin } \\
\hline $\begin{array}{l}\text { Carapetis et al. } \\
\text { (19) }\end{array}$ & Prospective & 84 & $\begin{array}{l}\text { Children and adults } \\
\text { (Average age of the } \\
\text { two groups } \\
\text { compared: } 56.2 \text { and } \\
70.4 \text { years) }\end{array}$ & $\begin{array}{l}\beta \text {-lactam + Clindamycin vs. } \\
\text { only } \beta \text {-lactam }\end{array}$ & $\begin{array}{l}\text { OR mortality: } 0.31 \text { (95\% Cl: } \\
\left.0.09-1.12^{\#}\right)\end{array}$ & $\begin{array}{l}\text { Combination of } \beta \text {-lactam }+ \\
\text { clindamycin decreases mortality } \\
\text { in case of STSS or NF }\end{array}$ \\
\hline $\begin{array}{l}\text { Zimbelman et al. } \\
\text { (35) }\end{array}$ & Retrospective & 56 & $\begin{array}{l}\text { Children (Average } \\
\text { age: } 3.8 \text { years) }\end{array}$ & $\begin{array}{l}\text { Clindamycin ( } \pm \beta \text {-lactam) vs } \\
\text { only } \beta \text {-lactam }\end{array}$ & $\begin{array}{l}\text { Favorable outcome: } 83 \% \\
\text { (vs. 14\%) }\left(p=0.006^{\star}\right)\end{array}$ & $\begin{array}{l}\text { Patients with deep infection (NF, } \\
\text { bacteremia, arthritis, } \\
\text { osteomyelitis) were more likely } \\
\text { to have a favorable outcome if } \\
\text { initial treatment included } \\
\text { clindamycin }\end{array}$ \\
\hline Mulla et al. (36) & Retrospective & 195 & $\begin{array}{l}\text { Adults (Average age: } \\
52 \text { years) }\end{array}$ & $\begin{array}{l}\text { Only clindamycin or in } \\
\text { combination Vs. no } \\
\text { clindamycin }\end{array}$ & $\begin{array}{l}\text { OR mortality in NF: } 0.11 \\
\left(95 \% \mathrm{Cl}: 0.01-0.89^{*}\right)\end{array}$ & $\begin{array}{l}\text { Clindamycin decreases } \\
\text { mortality in case of NF }\end{array}$ \\
\hline
\end{tabular}




\begin{tabular}{|c|c|c|c|c|c|c|}
\hline References & $\begin{array}{l}\text { Design } \\
\text { study }\end{array}$ & $\begin{array}{l}\text { Number } \\
\text { of } \\
\text { patients }\end{array}$ & Type of patients & Treatments compared & Results & Conclusions \\
\hline Linnér et al. (21) & Prospective & 67 & $\begin{array}{l}\text { Adults (Average age } \\
\text { of the two groups: } \\
60 \text { vs. } 65 \text { years old) }\end{array}$ & $\begin{array}{l}\text { Clindamycin vs. no } \\
\text { clindamycin }\end{array}$ & $\begin{array}{l}\text { OR survival: } 8.6(95 \% \mathrm{Cl} \\
\left.1.8-40.4, p=0.007^{\star}\right)\end{array}$ & $\begin{array}{l}\text { Clindamycin decrease mortality } \\
\text { in STSS }\end{array}$ \\
\hline $\begin{array}{l}\text { Babiker et al. } \\
\text { (37) }\end{array}$ & Retrospective & 1,956 & $\begin{array}{l}\text { Adults (Average age } \\
\text { of the two groups } \\
\text { compared: } 48 \text { vs. } 47 \\
\text { years) }\end{array}$ & $\begin{array}{l}\text { Clindamycin vs. no } \\
\text { clindamycin }\end{array}$ & $\begin{array}{l}\text { OR mortality: } 0.44 \text { (95\% IC: } \\
\left.0.23-0.81^{\star}\right)\end{array}$ & $\begin{array}{l}\text { Clindamycin decrease mortality } \\
\text { in case of iGAS with or without } \\
\text { shock or NF }\end{array}$ \\
\hline
\end{tabular}

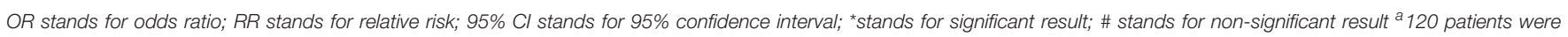

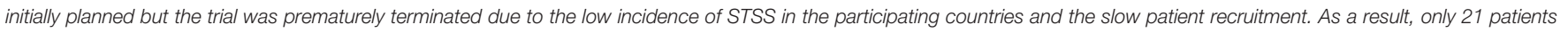
were included.

the use of clindamycin in case of NF, STSS, or toxin signs (rash, digestive, or hemodynamic disorders) (17). However, indications in other severe cases remain a matter of debate. As clindamycin is a relatively safe and inexpensive molecule (38), we propose to use a $\beta$-lactam-clindamycin combination to treat all serious iGAS infections which need to be treated in a hospital.

\section{Benefit of Secondary Antibiotics Prophylaxis}

Outbreaks of iGAS have been reported in homecare facilities, hospitals, schools, as well as in close contacts of a patient who presented a recent iGAS episode $(15,43,44)$. Adults experiencing homelessness are also at risk of iGAS $(44,45)$. These people cumulate risk factors for GAS colonization, such as crowding and skin breakdown and often underlying medical conditions and alcohol abuse (44-46). Definition of close contacts for iGAS includes people who were closely in contact with the index case during the seven days preceding the onset of symptoms and up to $24 \mathrm{~h}$ after the onset of antibiotic therapy in the index case. The close contacts shared the same home; had intimate physical contact (people who have had sex or spent at least $50 \%$ of the nights in the same house); persons attending institutions (childcare, homes for the elderly, prisons, military camps, etc.) and staff members; persons who have had direct physical contact via mucous membrane or damaged skin with nasal or pharyngeal secretion of the index case $(10,11,15,46)$.

Five population-based studies evaluated the risk of secondary infections in close contacts of a patient who developed an iGAS and all found an increased risk compared to the general population. Four studies performed in England, USA, Canada, and Australia demonstrated an increased risk ranging from 229 to 2,011 times higher for household contacts compared to the general population $(19,47-49)$. Another UK study published in 2017 found an increased odds to develop an iGAS for a mother or her newborn if either of them has an iGAS during the first 28 days after delivery with a 1,940 (95\% CI: 1,240-2,880)-fold increase (50).

The risk of secondary iGAS in close contacts is higher within the first 7 days and remains high until 30 days after the last contact with the index case $(19,43,47,49)$. All the papers above unanimously demonstrated that close contacts of an iGAS patient are more prone to develop the infection compare to the general population, similarly to what is observed in the case of meningococcemia (51). However, in contrary to meningococcal diseases for which the prescription of antibiotics prophylaxis to close relatives is commonly admitted, there is no consensus regarding secondary prophylaxis after iGAS (52). Even though the risk of iGAS among close contacts is higher than the general population, it remains low (12). In addition, no study has demonstrated a reduction in the risk of iGAS in close contacts after a chemoprophylaxis. The effective treatment of pharyngitis or oropharyngeal carriage of GAS has been proven with 10 days of penicillin associated with rifampin (4 days) or 10 days of clindamycin $(53,54)$. Cephalosporins have also been shown to be more effective than penicillin for pharyngitis in GAS $(55,56)$. In addition, an important fear is that taking chemoprophylaxis may falsely reassure patients and delay their presentation to the emergency room (57). It would be useful to carry out studies on the effect of chemoprophylaxis administered to at-risk groups on the occurrence of secondary cases of iGAS and to monitor whether these attitudes will lead to the emergence of resistance.

The Centers for Disease Control and Prevention (CDC), the Superior Council of Public Hygiene of France, the British Infectious Disease Association, and the Center for Disease Control in the Northern Territory of Australia recommend to inform close contacts about the potential risk of developing iGAS, notably by explaining the clinical manifestations of pharyngeal or invasive GAS infections and the importance of prompt medical consultation in case these symptoms will appear during the month following infection in the index case (10-13). It is also advisable to treat close cases if any of them has a localized infection such as pharyngitis, skin infection, and/or fever $(1,12)$. Performing a throat swab to assess GAS carriage is considered useless to guide chemoprophylaxis (15). In some cases, a chemoprophylaxis can be proposed (Table 1). Indications for antibioprophylaxis widely differ according to the regions of the world but everyone agrees that if a chemoprophylaxis is prescribed, it should be administered as quickly as possible, ideally within the 24 hours after the diagnosis of the index case and up to 7 (15) to 30 days (11) after the last contact. The GAS colonization increase in close contacts who were 
exposed at least $24 \mathrm{~h} /$ week to the index patient (36 vs. 2\%) (58).

In the USA and France, a chemoprophylaxis is recommended only for household contacts with a high risk of iGAS (age $\geq 65$ years, HIV infection, diabetes, cancer, heart disease, addiction, corticosteroids, Native American origin) or death (10, 13, 14). In Canada, a chemoprophylaxis is prescribed for all close contacts of patients with a severe iGAS (regardless of his underlying medical conditions) or to the members of a community where two or more cases occurred within the same month (15). In Great Britain and Ireland, a chemoprophylaxis is given to a mother or her child if either has presented with suspected or confirmed iGAS during the neonatal period (the first 28 days of life) or to all members of a community where two or more cases occurred within the same month $(12,16)$. The theoretical number needed to treat (NNT) to prevent one secondary case using antibiotic prophylaxis was evaluated to 271 overall (95\% CI: 194-454) and to 50 for mother-neonate pairs (95\% CI: 27393) (50). In Australia, a chemoprophylaxis will be advised in three kinds of situations: for all close contacts of a patient with a severe iGAS, for a mother or her child if either has a suspected or confirmed iGAS within 28 days of birth, and for all asymptomatic institutional contacts if two or more cases occurred in a community within 3 months (11). Finally, in Belgium and particularly in Flanders, a chemoprophylaxis is prescribed to all household members of the index case (18). We recommend that all contacts of an iGAS patient must be informed about the higher risk of developing iGAS and the importance of prompt medical consultation if symptoms appear during the following month. For serious iGAS requiring treatment at a hospital, we also recommend chemoprophylaxis for all household members of the patient including motherbaby couples who have the highest risk of secondary iGAS. We also recommend prophylaxis for people at a high risk of complications or deaths related to iGAS, both children and elderly people (Table 1). We suggest using a first-generation cephalosporins for 10 days [cefadroxil $30 \mathrm{mg} / \mathrm{kg} /$ day (maximum

\section{REFERENCES}

1. Steer AC, Lamagni T, Curtis N, Carapetis JR. Invasive group a streptococcal disease: epidemiology, pathogenesis and management. Drugs. (2012) 72:121327. doi: 10.2165/11634180-000000000-00000

2. Carapetis JR, Steer AC, Mulholland EK, Weber M. The global burden of group A streptococcal diseases. Lancet Infect Dis. (2005) 5:685-94. doi: 10.1016/S1473-3099(05)70267-X

3. Vannice KS, Ricaldi J, Nanduri S, Fang FC, Lynch JB, Bryson-Cahn C, et al. Streptococcus pyogenes $\mathrm{pbp} 2 \mathrm{x}$ mutation confers reduced susceptibility to $\beta$ Lactam antibiotics. Clin Infect Dis Off Publ Infect Dis Soc Am. (2020) 71:201-4. doi: $10.1093 / \mathrm{cid} / \mathrm{ciz} 1000$

4. O'Loughlin RE, Roberson A, Cieslak PR, Lynfield R, Gershman K, Craig A, et al. The epidemiology of invasive group A streptococcal infection and potential vaccine implications: United States, 2000-2004. Clin Infect Dis Off Publ Infect Dis Soc Am. (2007) 45:853-62. doi: 10.1086/521264

5. Commons RJ, Smeesters PR, Proft T, Fraser JD, Robins-Browne R, Curtis N. Streptococcal superantigens: categorization and clinical associations. Trends Mol Med. (2014) 20:48-62. doi: 10.1016/j.molmed.2013.10.004 daily dose, $2 \mathrm{~g}$ /day) in two or three divided doses] and keep azithromycin for 3 days $[10 \mathrm{mg} / \mathrm{kg} /$ day (maximum daily dose, $500 \mathrm{mg} /$ day) in a single dose] only for people who are allergic to beta-lactams (59). We do not recommend testing for macrolide sensitivity to avoid chemoprophylaxis administration delay and because of the relatively low frequency of macrolides resistance in most settings. Nevertheless, if the GAS strain isolated from the index case is found to be resistant to macrolides or for pregnant women, clindamycin should be prescribed for 10 days [20 $\mathrm{mg} / \mathrm{kg} / \mathrm{day}$ (maximum daily dose, $900 \mathrm{mg} /$ day) in three divided doses]. Regarding caregivers, as the contact with the patient occurs $<24 \mathrm{~h}$ per week, the risk of secondary iGAS is probably low (58).

\section{CONCLUSIONS}

Conclusive clinical evidence regarding the benefit of adjunctive clindamycin, IVIG, and secondary prophylaxis for iGAS patient are unlikely to arise. However, a convergent body of in vitro, in vivo, and ex vivo animal and human clinical data suggest that clindamycin and IVIG should be used as adjunctive therapies when possible. Physicians must also be warned of the increased risk of iGAS in close contacts for 28 days and should inform the close contacts of their patients. Antibiotic prophylaxis in such iGAS close contacts may reduce the risk of developing the disease.

\section{AUTHOR CONTRIBUTIONS}

PS and DL contributed to conception of the review. DL wrote the first draft of the manuscript. PS made important improvements of the manuscript. All authors contributed to manuscript revision, read, and approved the submitted version.

\section{FUNDING}

This work was supported by The Belgian Kids' Fund for Pediatric Research and by the by FNRS research grants (PDR T.0227.20).
6. Botteaux A, Budnik I, Smeesters PR. Group A Streptococcus infections in children: from virulence to clinical management. Curr Opin Infect Dis. (2018) 31:224-30. doi: 10.1097/QCO.0000000000000452

7. Nookala S, Krishnan KC, Mukundan S, Kotb M. Systems genetics approaches in mouse models of group a streptococcal necrotizing soft-tissue infections. In: Norrby-Teglund A, Svensson M, Skrede S, éditors. Necrotizing Soft Tissue Infect Clin Pathog Asp. Cham: Springer International Publishing (2020). p. 151-66. doi: 10.1007/978-3-030-57616-5_10

8. Remmington A, Turner CE. The DNases of pathogenic Lancefield streptococci. Microbiology. (2018)164:242-50. doi: 10.1099/mic.0.000612

9. Wilkins AL, Steer AC, Smeesters PR, Curtis N. Toxic shock syndrome the seven Rs of management and treatment. J Infect. (2017) 74:S147-52. doi: 10.1016/S0163-4453(17)30206-2

10. Prevention of Invasive Group A Streptococcal Infections Workshop Participants. Prevention of invasive group A streptococcal disease among household contacts of case patients and among postpartum and postsurgical patients: recommendations from the Centers for Disease Control and Prevention. Clin Infect Dis Off Publ Infect Dis Soc Am. (2002) 35:950-9. doi: $10.1086 / 342692$ 
11. Centre for Disease Control, Northern Territory of Australia. Public Health Management of Invasive Group A Streptococcal Infection. Darwin, (2015).

12. Health Protection Agency, Group A Streptococcus Working Group. Interim UK guidelines for management of close community contacts of invasive group A streptococcal disease. Commun Dis Public Health. (2004). 7:354-61. Available online at : https://assets.publishing.service.gov.uk/government/ uploads/system/uploads/attachment_data/file/344610/Interim_guidelines_ for_management_of_close_contacts_of_iGAS.pdf

13. Conseil Supérieur d'Hygiène Publique de France, Section des Maladies Transmissibles 2005. Avis relatif à la conduite à tenir autour d'un ou de plusieurs cas, d'origine communautaire, dinfections invasives à Streptococcus pyogenes (ou streptocoques du groupe A) séance du 18 Novembre. (2005) Paris: Ministère de la Santé.

14. Kimberlin DW, Brady MT, Jackson MA, Long SS, eds. Red Book: 2015 Report of the Committee on Infectious Diseases. 30th edn. Elk Grove Village, IL: American Academy of Pediatrics (2015). p. 732-747.

15. Moore DL, Allen UD, Mailman T. Invasive group A streptococcal disease: Management and chemoprophylaxis. Paediatr Child Health. (2019) 24:128-9. doi: $10.1093 / \mathrm{pch} / \mathrm{pxz} 039$

16. Health Protection Surveillance Centre. The Managment of Invasive Group A Streptococcal Infections in Ireland. Invasive group A streptococcus SubCommittee. Dublin, (2006).

17. Faye A, Lorrot M, Bidet P, Bonacorsi S, Cohen R. [Management of severe invasive group A streptococcal infections]. Arch Pediatr Organe Off Soc Francaise Pediatr. (2014) 21(Suppl. 2):S87-92. doi: 10.1016/S0929-693X(14)72267-5

18. Agentschap zorg \& gezonheid. Groep A Streptokokkeninfecties: Roodvonk, Krentenbaard, Acuut Reuma, Invasieve Infectie. [Internet]. (2016). Available online at : https://www.zorg-en-gezondheid.be/sites/default/files/atoms/files/ Richtlijn\%20Groep\%20A-streptokokkeninfectie_2016.pdf (accessed May 23, 2019).

19. Carapetis JR, Jacoby P, Carville K, Ang S-JJ, Curtis N, Andrews R. Effectiveness of clindamycin and intravenous immunoglobulin, and risk of disease in contacts, in invasive group a streptococcal infections. Clin Infect Dis Off Publ Infect Dis Soc Am. (2014) 59:358-65. doi: 10.1093/cid/ciu304

20. Schilcher K, Andreoni F, Uchiyama S, Ogawa T, Schuepbach RA, Zinkernagel AS. Increased neutrophil extracellular trap-mediated Staphylococcus aureus clearance through inhibition of nuclease activity by clindamycin and immunoglobulin. J Infect Dis. (2014) 210:473-82. doi: 10.1093/infdis/jiu091

21. Linnér A, Darenberg J, Sjölin J, Henriques-Normark B, Norrby-Teglund A. Clinical efficacy of polyspecific intravenous immunoglobulin therapy in patients with streptococcal toxic shock syndrome: a comparative observational study. Clin Infect Dis Off Publ Infect Dis Soc Am. (2014) 59:851-7. doi: 10.1093/cid/ciu449

22. Sriskandan S, Ferguson M, Elliot V, Faulkner L, Cohen J. Human intravenous immunoglobulin for experimental streptococcal toxic shock: bacterial clearance and modulation of inflammation. J Antimicrob Chemother. (2006) 58:117-24. doi: 10.1093/jac/dkl173

23. Reglinski M, Gierula M, Lynskey NN, Edwards RJ, Sriskandan S. Identification of the Streptococcus pyogenes surface antigens recognised by pooled human immunoglobulin. Sci Rep. (2015) 5:15825. doi: 10.1038/srep15825

24. Tarnutzer A, Andreoni F, Keller N, Zürcher C, Norrby-Teglund A, Schüpbach RA, et al. Human polyspecific immunoglobulin attenuates group A streptococcal virulence factor activity and reduces disease severity in a murine necrotizing fasciitis model. Clin Microbiol Infect Off Publ Eur Soc Clin Microbiol Infect Dis. (2019) 25:512.e7-512.e13. doi: 10.1016/j.cmi.2018.07.007

25. Norrby-Teglund A, Kaul R, Low DE, McGeer A, Newton DW, Andersson J, et al. Plasma from patients with severe invasive group A streptococcal infections treated with normal polyspecific IgG inhibits streptococcal superantigeninduced $\mathrm{T}$ cell proliferation and cytokine production. J Immunol Baltim Md. (1996) 156:3057-64.

26. Bergsten H, Madsen MB, Bergey F, Hyldegaard O, Skrede S, Arnell P, et al. Correlation between immunoglobulin dose administered and plasma neutralization of streptococcal superantigens in patients with necrotizing soft tissue infections. Clin Infect Dis Off Publ Infect Dis Soc Am. (2020) 71:1772-5. doi: $10.1093 /$ cid/ciaa022

27. Kaul R, McGeer A, Norrby-Teglund A, Kotb M, Schwartz B, O'Rourke K, et al. Intravenous immunoglobulin therapy for streptococcal toxic shock syndrome-a comparative observational study. The Canadian Streptococcal Study Group. Clin Infect Dis Off Publ Infect Dis Soc Am. (1999) 28:800-7. doi: $10.1086 / 515199$

28. Darenberg J, Ihendyane N, Sjölin J, Aufwerber E, Haidl S, Follin P, et al. Intravenous immunoglobulin $\mathrm{G}$ therapy in Streptococcal toxic shock syndrome: a european randomized, double-blind, placebo-controlled trial. Clin Infect Dis. (2003) 37:333-40. doi: 10.1086/376630

29. Kadri SS, Swihart BJ, Bonne SL, Hohmann SF, Hennessy LV, Louras P, et al. Impact of intravenous immunoglobulin on survival in necrotizing fasciitis with vasopressor-dependent shock: a propensity score-matched analysis from 130 US hospitals. Clin Infect Dis Off Publ Infect Dis Soc Am. (2017) 64:877-85. doi: $10.1093 / \mathrm{cid} / \mathrm{ciw} 871$

30. Madsen $M B$, Hjortrup $\mathrm{PB}$, Hansen $\mathrm{MB}$, Lange $T$, Norrby-Teglund $A$, Hyldegaard $\mathrm{O}$, et al. Immunoglobulin $\mathrm{G}$ for patients with necrotising soft tissue infection (INSTINCT): a randomised, blinded, placebo-controlled trial. Intensive Care Med. (2017) 43:1585-93. doi: 10.1007/s00134-017-4786-0

31. Shah SS, Hall M, Srivastava R, Subramony A, Levin JE. Intravenous immunoglobulin in children with streptococcal toxic shock syndrome. Clin Infect Dis Off Publ Infect Dis Soc Am. (2009) 49:1369-76. doi: 10.1086/6 06048

32. Adalat $S$, Dawson $T$, Hackett SJ, Clark JE. In association with the British Paediatric Surveillance Unit. Toxic shock syndrome surveillance in UK children. Arch Dis Child. (2014) 99:1078-82. doi: 10.1136/archdischild-2013-304741

33. Alejandria MM, Lansang MAD, Dans LF, Mantaring JB. Intravenous immunoglobulin for treating sepsis, severe sepsis and septic shock. Cochrane Database Syst Rev. (2013) 2013:CD001090. doi: 10.1002/14651858.CD001090.pub2

34. Parks T, Wilson C, Curtis N, Norrby-Teglund A, Sriskandan S. Polyspecific intravenous immunoglobulin in clindamycin-treated patients with Streptococcal toxic shock syndrome: a systematic review and metaanalysis. Clin Infect Dis Off Publ Infect Dis Soc Am. (2018) 67:1434-6. doi: $10.1093 / \mathrm{cid} / \mathrm{ciy} 401$

35. Zimbelman J, Palmer A, Todd J. Improved outcome of clindamycin compared with beta-lactam antibiotic treatment for invasive Streptococcus pyogenes infection. Pediatr Infect Dis J. (1999) 18:1096-100. doi: 10.1097/00006454-199912000-00014

36. Mulla ZD, Leaverton PE, Wiersma ST. Invasive group A streptococcal infections in Florida. South Med J. (2003) 96:968-73. doi: 10.1097/01.SMJ.0000051060.95210.9A

37. Babiker A, Li X, Lai YL, Strich JR, Warner S, Sarzynski S, et al. Effectiveness of adjunctive clindamycin in $\beta$-lactam antibiotic-treated patients with invasive $\beta$-haemolytic streptococcal infections in US hospitals: a retrospective multicentre cohort study. Lancet Infect Dis. (2021) 21:697-710. doi: 10.1016/S1473-3099(20)30523-5

38. Résultat de la recherche. CBIP Available online at: https://www.cbip.be/fr/ keywords? $=\mathrm{q} \&$ \&type $=$ substance $($ accessed 25 January 2021).

39. Eagle H. Experimental approach to the problem of treatment failure with penicillin. I. Group A streptococcal infection in mice. Am J Med. (1952) 13:389-99. doi: 10.1016/0002-9343(52)90293-3

40. Stevens DL, Gibbons AE, Bergstrom R, Winn V. The eagle effect revisited: efficacy of clindamycin, erythromycin, and penicillin in the treatment of streptococcal myositis. J Infect Dis. (1988) 158:23-8. doi: 10.1093/infdis/158.1.23

41. Sriskandan S, McKee A, Hall L, Cohen J. Comparative effects of clindamycin and ampicillin on superantigenic activity of Streptococcus pyogenes. $J$ Antimicrob Chemother. (1997) 40:275-7. doi: 10.1093/jac/40.2.275

42. Andreoni F, Zürcher C, Tarnutzer A, Schilcher K, Neff A, Keller N, et al. Clindamycin affects Group A Streptococcus virulence factors and improves clinical outcome. J Infect Dis. (2017) 215:269-77. doi: 10.1093/infdis/jiw229

43. Carr JP, Curtis N, Smeesters PR, Steer A. QUESTION 1: are household contacts of patients with invasive group A streptococcal disease at higher risk of secondary infection? Arch Dis Child. (2016) 101:198-201. doi: 10.1136/archdischild-2015-309788

44. Mosites E, Zulz T, Bruden D, Nolen L, Frick A, Castrodale L, et al. Risk for invasive streptococcal infections among adults experiencing homelessness, Anchorage, Alaska, USA, 2002-2015. Emerg Infect Dis. (2019) 25:1911-8. doi: $10.3201 /$ eid2510.181408 
45. Adebanjo T, Mosites E, Van Beneden CA, Onukwube J, Blum M, Harper M, et al. Risk factors for Group A Streptococcus colonization during an outbreak among people experiencing homelessness in Anchorage, Alaska, 2017. Clin Infect Dis. (2018) 67:1784-7. doi: 10.1093/cid/ciy429

46. Middleton B, Morris P, Carapetis J. Invasive group A streptococcal infection in the Northern Territory, Australia: case report and review of the literature. $J$ Paediatr Child Health. (2014) 50:869-73. doi: 10.1111/jpc.12659

47. Davies HD, McGeer A, Schwartz B, Green K, Cann D, Simor AE, et al. Invasive group A streptococcal infections in Ontario, Canada. Ontario Group A Streptococcal Study Group. N Engl J Med. (1996) 335:547-54. doi: 10.1056/NEJM199608223350803

48. Lamagni TL, Oliver I, Stuart JM. Global assessment of invasive group a streptococcus infection risk in household contacts. Clin Infect Dis Off Publ Infect Dis Soc Am. (2015) 60:166-7. doi: 10.1093/cid/ciu752

49. Robinson KA, Rothrock G, Phan Q, Sayler B, Stefonek K, Van Beneden C, et al. Risk for severe Group A Streptococcal disease among patients' household contacts. Emerg Infect Dis. (2003) 9:443-7. doi: 10.3201/eid0904.020369

50. Mearkle R, Saavedra-Campos M, Lamagni T, Usdin M, Coelho J, Chalker V, et al. Household transmission of invasive group A Streptococcus infections in England: a population-based study, 2009. 2011 to 2013. Euro Surveill Bull Eur Sur Mal Transm Eur Commun Dis Bull. (2017). 22:30532. doi: 10.2807/1560-7917.ES.2017.22.19.30532

51. Zalmanovici Trestioreanu A, Fraser A, Gafter-Gvili A, Paul M, Leibovici L. Antibiotics for preventing meningococcal infections. Cochrane Database Syst Rev. (2013) 2013 :CD004785. doi: 10.1002/14651858.CD004785.pub5

52. National Collaborating Centre for Women's and Children's Health (UK). Bacterial Meningitis and Meningococcal Septicaemia: Management of Bacterial Meningitis and Meningococcal Septicaemia in Children and Young People Younger than 16 Years in Primary and Secondary Care [Internet]. London: RCOG Press (2010). Available online at: http://www.ncbi.nlm.nih.gov/books/ NBK83078/ (accessed 9 août 2018).

53. Chaudhary S, Bilinsky SA, Hennessy JL, Soler SM, Wallace SE, Schacht CM, et al. Penicillin V and rifampin for the treatment of group A streptococcal pharyngitis: a randomized trial of 10 days penicillin vs 10 days penicillin with rifampin during the final 4 days of therapy. J Pediatr. (1985) 106:481-6. doi: 10.1016/S0022-3476(85)80687-9

54. Tanz RR, Poncher JR, Corydon KE, Kabat K, Yogev R, Shulman ST. Clindamycin treatment of chronic pharyngeal carriage of group A streptococci. J Pediatr. (1991) 119:123-8. doi: 10.1016/S0022-3476(05)81052-2
55. Casey JR, Pichichero ME. Meta-analysis of cephalosporin versus penicillin treatment of group A streptococcal tonsillopharyngitis in children. Pediatrics. (2004) 113:866-82. doi: 10.1542/peds. 113.4.866

56. Casey JR, Pichichero ME. Meta-analysis of cephalosporins versus penicillin for treatment of group A streptococcal tonsillopharyngitis in adults. Clin Infect Dis Off Publ Infect Dis Soc Am. (2004) 38:1526-34. doi: 10.1086/ 392496

57. Smith A, Lamagni TL, Oliver I, Efstratiou A, George RC, Stuart JM. Invasive group A streptococcal disease: should close contacts routinely receive antibiotic prophylaxis? Lancet Infect Dis. (2005) 5:494-500. doi: 10.1016/S1473-3099(05)70190-0

58. de Almeida Torres RSL, dos Santos TZ, Torres RA de A, Petrini LMC de M, Burger M, Steer AC, et al. Management of contacts of patients with severe invasive group a streptococcal infection. J Pediatr Infect Dis Soc. (2016) 5:47-52. doi: 10.1093/jpids/piu107

59. Malhotra-Kumar S, Lammens C, Coenen S, Van Herck K, Goossens H. Effect of azithromycin and clarithromycin therapy on pharyngeal carriage of macrolide-resistant streptococci in healthy volunteers: a randomised, double-blind, placebo-controlled study. Lancet Lond Engl. (2007) 369:482-90. doi: 10.1016/S0140-6736(07)60235-9

Conflict of Interest: The authors declare that the research was conducted in the absence of any commercial or financial relationships that could be construed as a potential conflict of interest.

Publisher's Note: All claims expressed in this article are solely those of the authors and do not necessarily represent those of their affiliated organizations, or those of the publisher, the editors and the reviewers. Any product that may be evaluated in this article, or claim that may be made by its manufacturer, is not guaranteed or endorsed by the publisher.

Copyright (C) 2021 Laho, Blumental, Botteaux and Smeesters. This is an open-access article distributed under the terms of the Creative Commons Attribution License (CC $B Y)$. The use, distribution or reproduction in other forums is permitted, provided the original author(s) and the copyright owner(s) are credited and that the original publication in this journal is cited, in accordance with accepted academic practice. No use, distribution or reproduction is permitted which does not comply with these terms. 